\title{
CONSIDERATIONS IN REGARDS TO THE PROTECTION OF PERSONAL RIGHTS GRANTED AFTER THE PERSON'S DEATH
}

\author{
L-D., RATH BOȘCA, B. BODEA
}

\section{LAURA-DUMITRANA RATH BOȘCA}

Faculty of Juridical and Administrative Sciences, Romania

Agora University of Oradea, România

Doctoral School-Law Field

"UVT" University, Timișoara, Romania

*Correspondence: Laura-Dumitrana Rath Boșca, Agora University of Oradea, Piața

Tineretului no. 8, Oradea, Romania

E-mail: dumitra1970@yahoo.com

\section{BOGDAN BODEA}

Faculty of Law, University of Oradea, România

*Correspondence: Bogdan Bodea, Faculty of Law, University of Oradea, România, str.

General Magheru, no. 26, Oradea, România

E-mail: avocatbodea@yahoo.com

\section{ABSTRACT}

The present article aims to discuss the extent to which the protection granted to personal rights can exceed the life of a person and, if so, to determine whether the rights that come within the meaning of private life as governed by Article 8 of the European Convention of human rights can be protected consecutively to the person's death.

KEY WORDS: protection, personal rights, human rights, jurisprudence, reputation, deceased person, memory.

\section{INTRODUCTION}

In this regard the European Court of human rights has already confirmed the principle that Article 8 rights were non-transferable when it refused a universal legatee to pursue an application lodged by the immediate victim in the case of Thevenon v. France ${ }^{l}$.

In another decision the Court did not find sufficient reasons to depart from its established case-law and argued that the applicant does not have the legal standing to rely on his grandfather's rights under Article 8 of the Convention because of their non-transferable nature. $^{2}$

This being said, it seemed that the Court had a solid jurisprudence which established a temporal limit of protection for the private life: the death of the person. After this moment, any injury to the memory of the deceased was regarded as a violations of the rights of relatives that were alive.

\footnotetext{
${ }^{1}$ See Thevenon v. France Dec. no. 2476/02, 28 June 2006. In Thevenon v. France, mr Yahi an universal legatee of the plaintiff although a close friend of the deceased was denied locus standi on the bases that rights guaranteed by Articles 5 and 8 of the Convention are eminently personal and non-transferable

${ }^{2}$ Yakovlevich Dzhugashvili v. Russia, App. no. 41123/10, (dec.) 9 December 2014, §§ 23-24
} 


\section{CONSIDERATIONS IN REGARDS TO THE PROTECTION OF PERSONAL RIGHTS \\ GRANTED AFTER THE PERSON'S DEATH}

But the Court seems to depart from that opinion, in Genner $v$ Austria given the fact that it has found that there was no violation of the right to freedom of expression, in respect to sanctioning allegations that threatened the respect of private life of a deceased individual.

\section{GENNER VERSUS AUSTRIA}

In Genner The Court has found that Article $10 \S 2$ enables the reputation of others that is to say, of all individuals - to be protected. The right to protection of reputation is a right which is protected by Article 8 of the Convention as part of the right to respect for private life. An attack on a person's reputation must attain a certain level of seriousness and in a manner causing prejudice to personal enjoyment of the right to respect for private life $^{4}$.

Not wanting to set aside the well-established precedents, the Court emphasized that dealing appropriately with the dead out of respect for the feelings of the deceased's relatives falls within the scope of Article 8 (see with further references Hadri-Vionnet v. Switzerland, no. 55525/00, 51, 14 February 2008, Editions Plon v. France, cited above $\S 46$ and Putistin v. Ukraine, no. 16882/03, 33, 21 November 2013) $)^{5}$ and under art. 10 regardless of the forcefulness of political struggles, it is legitimate to try to ensure that they abide by a minimum degree of moderation and propriety, The reputation of a politician, even a controversial one, must benefit from the protection afforded by the Convention (Lindon, Otchakovsky-Laurens and July v. France, cited above, § 57). Moreover, a clear distinction must be made between criticism and insult. If the sole intent of a particular form of expression is to insult a person, an appropriate sanction would not, in principle, constitute a violation of Article 10 of the Convention (mutatis mutandis Kincses v. Hungary, no. 66232/10, § 33, 27 January 2015

But then the hole argumentation of the decision revolves around the rights of the deceased person, the Court stating that it agrees with the government that the interference did pursue the aim of the protection of "the reputation or rights of others", namely those of L.P. and the close members of her family - in particular her husband - which constitutes a legitimate aim within the meaning of paragraph 2 of Article 10 (see, Editions Plon v. France, cited above, § 34).

Furthermore considered that the press release which was issued on the day after the minister`s unexpected death, is a fact that intensified ,the impact of the words used and

\footnotetext{
${ }^{3}$ The applicant, Mr Michael Genner, an Austrian national worked for the association "Asyl in Not", which offers legal and social support to asylum seekers and refugees. On 31 December 2006 the then Federal Minister for Interior Affairs, L.P., died unexpectedly of an aneurysm at the age of 55 and the next day the applicant published a statement on the association's website entitled "One less. What's coming now?" and stated "The good news for the New Year: L.P., Minister for torture and deportation, is dead.", criticizing in harsh terms the activity of the minister stating that she was a desk war criminal just like many others there have been in the atrocious history of his country. G.P., the late Minister's husband, filed a private prosecution (Privatanklage) for defamation against the applicant and the association. On 19 September 2007 the Vienna Regional Court convicted the applicant of defamation. The decision was upheld by superior Courts

${ }^{4}$ Genner v. Austria $\$ 31-32$. Furthermore, The Court has reiterated the relevant principles which must guide its assessment and identified a number of criteria in the context of balancing the competing rights (see Von Hannover (no. 2), cited above, §§ 109-13, and Axel Springer AG v. Germany [GC], no. 39954/08, § 90-95, 7 February 2012). The relevant criteria thus defined are: contribution to a debate of public interest, the degree of notoriety of the person affected, the subject of the news report, the prior conduct of the person concerned, the content, form and consequences of the publication, and, where appropriate, the circumstances in which the statement was made (see Print Zeitungsverlag GmbH v. Austria, no. 26547/07, § 33, 10 October 2013 and mutatis mutandis Couderc and Hachette Filipacchi Associés v. France [GC], no. 40454/07, §93, 10 November 2015).

${ }^{5}$ Genner v. Austria $\$ 35$
} 


\section{Laura-Dumitrana Rath Boșca, Bogdan Bodea}

applicant's statement published within the immediate period of her family's grief and was likely to cause considerable damage to the late Minister's reputation ${ }^{6}$.

Timing of the impugned statement was considered to be a relevant circumstance in the case and was taken into consideration when balancing the conflicting rights under Article 8 and 10. The Court found the statement ${ }^{7}$ an expression of satisfaction with the sudden death of L.P., the applicant made the day after the person had passed away, and the Court stated that to express insult on the day after the death of the insulted person contradicts elementary decency and respect to human beings, and is an attack on the core of personality rights.

Given this considerations, we can argue that a change in the Court's view is possible. We cannot agree that the balance between articles 8 and 10 of the Convention reflects the interpretation already endorsed in Putistin $v$ Ukraine referring to the living relatives rights to be protected against distress or identity injury.

In Genner v. Austria the Court takes into consideration the attributes of the deceased person (that she was a former minister, a public person) and the degree of intrusiveness in her private life to check the balance. Given the fact that the relatives themselves cannot claim they were public figures, the standard would have been set higher than the Court has set them if the rights involved were that of the relatives.

The fact that the Court takes into consideration the deceased person itself (the public figure check) makes us think that the Court has seen this matter as a conflict between two rights: the freedom of expression of the plaintiff and the right to private life of the deceased.

Although this could be regarded as an expansion of the rights of a person after his or hers death, the provisions of article 8 does not prohibit such a protection against harmful activities, once the person is dead.

The nature of the problem from our point of view is a procedural one and it relates to the notion of being the victim of an alleged violation of the article 8. But this problem should be solved under the article 34 of the Convention and whether or not we are prepared to allow a dead person the quality of victim (and/or plaintiff) in front of the European Court of Human Rights.

The material right however is not affected by the death of the person. It's right to have his image protected falls within the protection set out by article 8 and does not diminish or perish after his death.

To resort to a fictitious construction in which we see the damage brought to the image of the dead person through the perspective of his relatives right is more laborious then actually admitting that the right itself survives the factual existence of the person.

\section{CONCLUSIONS}

\footnotetext{
${ }^{6}$ Genner v. Austria $\S 41$

${ }^{7}$ In regard to the content of the applicant's statement, the Court considers that the applicant did not discuss the subject matter in a general and substantial manner but immediately launched a personal attack on the late Minister. He first of all expressed satisfaction about her death, suggesting that no decent human should feel grief about her passing away, and then continuing by comparing her to high-ranking Nazi officials who had committed atrocities and war crimes during the Second World War by calling her a desk war criminal ("Schreibtischtäterin"). It is true that in the statement published on 9 January 2007 in the newspaper "Der Standard" the applicant apologised to the family of L.P. for his statement, but even before this Court he insisted that the comparison of L.P. to Nazi war criminals had been correct and justified. The Court, however, considers that, even if regarded as value judgements, such serious and particularly offensive comparisons immediately after L.P.s death demand a particularly solid factual basis. In this respect the Court considered that the applicant did not make any distinction between the person of L.P. and the politics she stood for from his point of view.
} 


\section{CONSIDERATIONS IN REGARDS TO THE PROTECTION OF PERSONAL RIGHTS \\ GRANTED AFTER THE PERSON'S DEATH}

The image of the person has to be protected even after his death, and the fact that we need someone -for instance the relatives- to pursue that protection from a procedural point of view does not mean that the right itself has to be exercised on behalf of these persons.

Therefore we argue that some rights of the deceased person may be protected under Convention provisions even after his death. Rights such as the right to have his image, memory or reputation protected and other rights that enter in effect after the deceased person's death such as the right to be buried - in a certain place or in a certain religious ceremony - can be the subject of protection under article 8 or 9 of the Convention, even after death, and still be regarded as the rights of the deceased not the rights of the relatives of the deceased.

\section{REFERENCES}

1. Thevenon v. France Dec. no. 2476/02, 28 June 2006;

2. Yakovlevich Dzhugashvili v. Russia, App. no. 41123/10, (dec.) 9 December 2014;

3. Genner v. Austria §31-32. Furthermore;

4. Von Hannover (no. 2);

5. Axel Springer AG v. Germany [GC], no. 39954/08, § 90-95, 7 February 2012;

6. Print Zeitungsverlag GmbH v. Austria, no. 26547/07, § 33, 10 October 2013;

7. mutatis mutandis Couderc and Hachette Filipacchi Associésv. France [GC], no. 40454/07, § 93, 10 November 2015. 